\title{
DINAMIKA PENDUDUK DAN PERTUMBUHAN EKONOMI DI INDONESIA
}

\author{
Adhitya Wardhana ${ }^{1}$ \\ Bayu Kharisma ${ }^{2}$ \\ Sarah Annisa Noven ${ }^{3}$
}

Fakultas Ekonomi dan Bisnis Universitas Padjadjaran, Jawa Barat, Indonesia ${ }^{1,2,3}$

Email :adhitya.wardhana@fe.unpad.ac.id

\begin{abstract}
Population Dynamics and Economic Growth in Indonesia. This study aims to see the effect of population dynamics variables on economic growth in Indonesia. This study uses the Ordinary Least Square model with time series data from 1986 to 2016. The data used are population dynamics variables, such as number of fertilities, infant mortality, with the variable control are the amount of labor, savings and government expenditure on economic growth. The results os the study showed that the fertility amount in Indonesia has a negative effect on the amount of economic growth in Indones. Variable infant mortality has a negative influence on economic growth in Indonesia. Fertility variables and the population of productive age have a positive effect on labor force participation rates. Control variables, like savings and government expenditure, also have a positive effect on economic growth in Indonesia.
\end{abstract}

Keywords: Dynamics; Fertility; Infant Mortality; Labor; Economic Growth in Indonesia.

\begin{abstract}
Abstrak: Dinamika Penduduk Dan Pertumbuhan Ekonomi Di Indonesia. Penelitian ini bertujuan untuk melihat pengaruh variabel dinamika populasi terhadap pertumbuhan ekonomi di Indonesia. Penelitian ini menggunakan model Ordinary Least Square dengan data deret waktu dari 1986 hingga 2016. Data yang digunakan adalah variabel dinamika populasi, seperti jumlah kesuburan, kematian bayi, dengan variabel kontrol adalah jumlah tenaga kerja, tabungan dan pengeluaran pemerintah untuk ekonomi. Hasil penelitian menunjukkan bahwa jumlah kesuburan di Indonesia memiliki efek negatif pada jumlah pertumbuhan ekonomi di Indonesia. Variabel kematian bayi memiliki pengaruh negatif terhadap pertumbuhan ekonomi di Indonesia. Variabel kesuburan dan populasi usia produktif memiliki efek positif pada tingkat partisipasi angkatan kerja. Variabel kontrol, seperti tabungan dan pengeluaran pemerintah, juga memiliki efek positif pada pertumbuhan ekonomi di Indonesia.
\end{abstract}

Kata kunci: Dinamika; Fertilitas; Kematian Bayi; Tenaga Kerja; Pertumbuhan Ekonomi di Indonesia. 
Adhitya Wardhana, Bayu Kharisma, dan Sarah Annisa Noven. Dinamika Penduduk dan Pertumbuhan..... 23

\section{PENDAHULUAN}

Kependudukan menjadi salah satu faktor yang mempengaruhi pertumbuhan ekonomi di suatu wilayah(Jhingan, 2000). Penduduk sebagai motorik dalam roda perekonomian mengalami pertumbuhan yang cepat di dunia. Pertumbuhan penduduk ini akan memberikan pengaruh yang cukup besar bagi perekonomian seperti dialami oleh negara-negara berkembang termasuk Indonesia. Implikasi dari penduduk yang dilihat dari segi ukuran, pengembangan dan kualitas sangat penting untuk dipertimbangkan dalam perencanaan pembangunan ekonomi yang layak di masa yang akan datang (Aidi,2016).

Dinamika penduduk adalah kondisi di saat struktur penduduk, jumlah dan persebarannya mengalami perubahan akibat terjadinya proses demografi yaitu kelahiran, kematian, perpindahan (Bappenas,2013). Pertumbuhan penduduk menurut Lucas, Donald \& Young (1990) dipengaruhi oleh tiga elemen utama yaitu fertilitas (kelahiran), mortalitas (kematian), dan migrasi. Tingkat fertilitas memberikan pengaruh positif terhadap laju pertumbuhan penduduk atau menambah jumlah penduduk, sedangkan tingkat mortalitas memberikan pengaruh negatif atau faktor pengurang terhadap laju pertumbuhan penduduk. Migrasi penduduk yang telah mencapai pendidikan tersier mungkin akan meninggalkan negara dan menggunakan keterampilan dan kecerdasan mereka untuk membantu pengembangan negara lain yang berdampak terhadap penurunan perekonomian di suatu negara (Stephen, et al 2003). Dinamika penduduk tersebut dapat mempengaruhi pembangunan dalam mendorong pertumbuhan ekonomi, ketika jumlah penduduk semakin besar maka perlu diiikuti dengan kualitas penduduk yang memadai sehingga dapat menjadi modal bagi pertumbuhan ekonomi. Namun sebaliknya akan menjadi beban bagi suatu negara jika kualitas penduduknya rendah dan menghambat pembangunan.

Indonesia memiliki sumberdaya alam berlimpah dan ukuran populasi manusia yang besar. Dengan jumlah penduduk terbanyak ke empat di dunia, Indonesia telah menerapkan kebijakan ekonomi yang beragam jumlahnya sebagai upaya untuk memperbaiki standar hidup penduduknya untuk meningkatkan pertumbuhan ekonomi yang berkelanjutan. Jumlah penduduk Indonesia terus mengalami pertambahan setiap tahunnya. Menurut Badan Pusat Statistik (2018) menyebutkan jumlah 
penduduk Indonesia pada tahun 2010 berjumlah 242.518 ribu jiwa, kemudian jumlahnya pada tahun 2017 mengalami peningkatan menjadi 261.890 ribu jiwa. Indonesia mengalami laju pertumbuhan sebesar 1.49 persen atau sekitar empat juta jiwa pertahun dan termasuk kedalam kategori sedang karena tumbuh berkisar 1-2 persen pertahun. Sedangkan target pertumbuhan penduduk Indonesia sebesar 1.19 persen atau sekitar satu sampai dua juta pertahun (BKKBN, 2018).

Dua faktor penting yang mempengaruhi dinamika penduduk yaitu faktor alamiah kelahiran dan kematian. Angka kelahiran yang diukur dengan Total Fertility Rate (TFR) mencerminkan rata-rata banyaknya anak yang dilahirkan seorang wanita hingga akhir masa reproduksinya. Pemerintah telah melakukan upaya untuk menekan bertambahnya jumlah penduduk dengan mengendalikan angka kelahiran (Bappenas, 2017). Selain fertilitas, faktor lain yang mempengaruhi dinamika penduduk yaitu mortalitas. Menurut World Development Indicator (2017) mortalitas yang dilihat dari angka kematian bayi Indonesia menunjukkan bahwa jumlah kematian di tahun 2016 sebesar 22.2 per 1000 kelahiran hidup. Jumlah ini menunjukan bahwa masih tingginya angka kematian bayi di Indonesia jika dibandingkan dengan negara-negara tetangga ASEAN lain seperti Malaysia, Vietnam dan Thailand. Berikut ini gambar perbandingan mortalitas Indonesia dengan proksi angka kematian bayi (infant mortalitas) dengan empat negara ASEAN yaitu Malaysia, Philipina, Thailand dan Vietnam.

Mortalitas negara Indonesia dan Filiphina memiliki angka yang cukup besar dibandingkan tiga negara lainnya seperti Malaysia, Vietnam dan Thailand dalam tiga tahun 2015 hingga 2017. Rata-rata setiap lima negara ASEAN mengalami penurunan jumlah angka mortalitas tetapi melambat. Menurut Olabiyi (2004) sebagian besar negara-negara berkembang yang mengalami penurunan angka kematian bayi tidak disertai dengan penurunan angka kelahiran yang sama. Angka kematian bayi menurun berdampak baik terhadap kesejahteraan penduduk yang menggambarkan membaiknya kesehatan dan perekonomian secara umum.

Menurut Olabiyi (2004) terdapat beberapa faktor yang dianggap dapat mempengaruhi pertumbuhan ekonomi selain faktor kependudukan yaitu faktor yang digunakan 
sebagai variabel kontrol yang dianggap konstan. melakukan kegiatan produksi dan konsumsi Variabel terdiri atas pengeluaran pemerintah barang dan jasa. Sebaliknya menurut kaum (goverment expenditure), tingkat tabungan pesimis Malthusian, berpendapat bahwa (saving rate), Angka partisipasi sekolah dan semakin bertambah jumlah penduduk maka keterbukaan perdagangan (trade openess). akan membuat pertumbuhan ekonomi menurun, Hal yang sama dikemukakan oleh Aidi (2016) karena jumlah penduduk yang bertambah beberapa faktor yang dianggap mempengaruhi menimbulkan masalah seperti perencanaan pertumbuhan ekonomi yaitu fertilitas, yang sulit dan pembelanjaan pemerintah yang mortalitas, migrasi dan variabel kontrolnya meningkat untuk kependudukan.

yaitu pengeluaran pemerintah (goverment expenditure), tingkat tabungan (saving rate) dan keterbukaan perdagangan (trade openess).

Diperkirakan terdapat hubungan ketika fertilitas dan infant mortalitas menurun maka pada jangka panjang akan menciptakan penduduk yang berusia produktif sehingga membuat pola tabungan meningkat, kemudian tabungan dapat digunakan untuk kegiatan investasi. Peningkatan kegiatan investasi dalam hal ini dapat mengembangkan perdagangaan untuk meningkatkan pertumbuhan ekonomi yang diukur melalui Gross Domestic Product $(G D P)$. Menurut kaum optimis (Boserup, 1981; Simon, 1986; Kuznet,1974) berpendapat bahwa semakin bertambah jumlah penduduk dapat mendorong pertumbuhan ekonomi karena semakin bertambah penduduk yang
Jumlah penduduk Indonesia yang besar menjadi sebuah potensi sekaligus tantangan dalam pertumbuhan ekonomi. Pada dasarnya peran penduduk adalah subjek sekaligus objek pembangunan. Sebagai subjek, penduduk merupakan sumber daya penggerak pembangunan. Sementara itu sebagai obyek, penduduk adalah pihak yang dibangun sekaligus penikmat hasil pembangunan. Dengan demikian, penduduk adalah pelaku dan tujuan akhir dari pembangunan itu sendiri.

Dinamika penduduk dalam penelitian ini dilihat dari tren fertilitas dan mortalitas. Fertilitas dan mortalitas di Indonesia mengalami penurunan, sedangkan pertumbuhan ekonomi juga mengalami fluktuasi dan cenderung menurun. Namun dibandingkan dengan negara ASEAN lainnya tingkat mortalitas masih tinggi. 
Terjadi gap antara penelitian terdahulu yang menyatakan bahwa penurunan tingkat fertilitas akan meningkatkan laju pertumbuhan ekonomi dan peningkatan angka mortalitas membuat laju pertumbuhan ekonomi ikut meningkat.

Jumlah penduduk Indonesia memang terus bertambah, tetapi pertumbuhannya tidak sebanyak tahun sebelumnya dalam beberapa tahun terakhir. Perkembangan jumlah penduduk yang tinggijika tidak diikuti dengan pertumbuhan ekonomi yang seimbang maka akan berakibat kepada sumber daya manusia yang berkualitas rendah. Oleh sebab itu, perlu melihat apakah efektif atau tidaknya tindakan mengendalikan pertumbuhan penduduk agar permasalahan yang timbul bisa dikurangi. Adapun tujuan penelitian ini untuk mengetahui pengaruh antara dinamika penduduk (fertilitas dan infant mortalitas) terhadap pertumbuhan ekonomi dan mengetahui variabel dinamika penduduk yang paling mempengaruhi pertumbuhan ekonomi.

\section{METODE PENELITIAN}

Data yang digunakan dalam penelitian ini adalah data sekunder. Bentuk data adalah kuantitatif yang disusun time series dari tahun 1986-2016 dengan sampel negara Indonesia.
Data ini terdiri dari dua model, yang pertama variabel dependen adalah Tingkat Partisipasi Angkatan Kerja, dengan variabel independen adalah angka kelahiran dan infant mortalitas. Pada model kedua variabel dependen adalah GDP riil, dan variabel independen angka fertilitas, angka infant mortalitas, tingkat tabungan dan belanja pemerintah di Indonesia. Sumber data yang digunakan berasal dari lembaga dan instansi terkait seperti World Bank, World Development Indicator, Bank Indonesia dan Badan Pusat Statistik 2015. Data dalam penelitian ini diperoleh melalui metode riset kepustakaan berupa studi literature, tulisan ilmiah maupun artikel-artikel terkait dengan topik dinamika penduduk dan pertumbuhan ekonomi.

Analisis model data dalam penelitian ini menggunakan model ekonometrik, pengolahan data yang digunakan dalam penelitian adalah menggunakan metode analisis regresi Ordinary Least Square (OLS) untuk melihat pengaruh dari variabel independen terhadap variabel dependen dimana dalam penelitian ini adalah dinamika penduduk terhadap pertumbuhan ekonomi. Data bersifat kuantitatif dengan analisis statistik dari persamaan sederhana regresi linear. Spesifikasi 
model yang digunakan dalam penelitian ini ini dilakukan untuk mengetahui ada atau diambil dari penelitian sebelumnya dengan tidaknya penyimpangan asumsi klasik, mengacu pada model dari penelitian yang beberapa pengujian yang dilakukan meliputi dilakukan oleh Chrenshaw (1997), Bloom, D.E, Uji multikolinier. Penelitian ini menggunakan Canning \& Fink (2009) dan Aidi, Hakeem O, uji korelasi antar variabel dengan melihat niali dkk (2016). Untuk membantu penelitian ini Tolerance dan Variance Inflating Factor (VIF). digunakan analisis regresi OLS, berdasarkan Tolerance mengukur variabilitas dari independen literatur yang ada dan tujuan dari penelitian ini yang tidak dijelaskan oleh variabel independen model regresi akan dirumuskan sebagai berikut. lain. Nilai tolerance rendah sama dengan nilai Labor Supply $=\beta 0+\beta 1$ fertt $+\beta 2$ infm $+\varepsilon_{t \ldots .(1)}$ dimana labor supply adalah tingkat partisipasi angkatan kerja (\%), fert yaitu angka pertumbuhan kelahiran (\%), labor adalah angka pertumbuhan kematian (\%), terakhir $\varepsilon_{\mathrm{t}}$ yaitu error term. Selanjutnya, model ke 2 (dua) dapat dituliskan berikut ini.

$\ln R G D P_{t}=\beta_{0}+\beta_{l}$ lnfert $_{t}+\beta_{2} \operatorname{lnInfm}_{t+} \beta_{3} \operatorname{Sav}_{t+} \beta_{4}$ $\operatorname{lngov}{ }_{t}+\varepsilon_{t}$

dimana RGDP yaitu GDP riil Proksi dari pertumbuhan ekonomi, fert adalah total angka kelahiran (dalam jiwa), infm adalah total infant mortality rate (jiwa), sav yaitu total tabungan (\%), gov yaitu belanja pemerintah (rupiah) dan $\varepsilon_{\mathrm{t}}$ yaitu error term

\section{HASIL DAN PEMBAHASAN}

Dalam memenuhi syarat OLS, pengujian VIF yang tinggi.

$$
\mathrm{VIF}=\frac{1}{\text { Tolerance }}
$$

Nilai cutoff (batas) umumnya yang digunakan adalah Tolerance $<0.10$. dengan nilai tolerance 0.10 dan menggunakan nilai batas kritis 0.9 (Ghozali, 2013). Penelitian ini menghasilkan dalam persamaan GDPrill terhadap fertilitas, infant mortalitas, tabungan dan belanja pemerintah.

Pada Tabel 1 menunjukan bahwa hasil uji multikolinearitas menunjukkan tidak terdapat nilai korelasi yang tinggi antar variabel bebas karena tidak melebihi nilai 0.90 (Ghozali, 2013:83) sehingga dapat disimpulkan tidak terdapat masalah multikolinearitas antar variabel bebas.

Uji autokorelasi bertujuan untuk menguji apakah ada korelasi auto atau pengaruh data 
Tabel 1.

Correlation persamaan 2

\begin{tabular}{ccccc}
\hline & Fert & Infm & Saving & Gov \\
\hline Fert & 1 & 0.874089638242 & -0.382014226834 & -0.577543195956 \\
Infm & 0.87408963824 & 1 & -0.620494679797 & -0.864660435897 \\
Sav & -0.382014226834 & -0.620494679797 & 1 & 0.884689047141 \\
Gov & -0.577543195956 & -0.8646660435897 & 0.884689047142 & 1 \\
\hline
\end{tabular}

Sumber : data diolah, 2019

Tabel 2.

Hasil Uji Autokorelasi Persamaan 1

\begin{tabular}{lcll}
\hline Breusch- Godfrey Serial Correlation LM Test & \\
\hline F-statistic & 2.131806 & Prob. F(2,26) & 0.1405 \\
Obs*R-squared & 4.676401 & Prob. Chi-Square(2) & 0.0965 \\
\hline
\end{tabular}

Sumber : data diolah, 2019

Tabel 3.

Hasil Uji Autokorelasi Persamaan 2

\begin{tabular}{lcll}
\hline Breusch- Godfrey Serial Correlation LM Test & \\
\hline F-statistic & 7.877068 & Prob. F(2,24) & 0.0023 \\
Obs*R-squared & 12.28497 & Prob. Chi-Square(2) & 0.0021 \\
\hline
\end{tabular}

Sumber : data diolah, 2019

dari pengamatan sebelumnya dalam model ditolak, dan H0 tidak ditolak yang berarti tidak regresi. Uji autokorelasi pada penelitian ini terdapat autokorelasi.

dilakukan dengan uji Breusch - Godfrey Serial Hasil estimasi pada model dua, nilai

Correlation LM Test. $\quad$ obs*R-squared $\quad\left(\chi^{2}\right.$ hitung $)=12.28497<$

Hasil estimasi yang diperoleh 40.113 ( $\chi^{2}$ tabel) dengan level signifikansi menunjukkan bahwa pada model 1 nilai 5\%. nilai probabilitas obs*R-squared 0.0021 obs*R-squared $\left(\chi^{2}\right.$ hitung $)=4.676401<\chi^{2}$ tabel $<0.05$, maka H1 tidak ditolak atau berarti $=42.557$ pada level signifikan 5\%. Serta nilai terdapat masalah autokorelasi. Maka dengan probabilitas obs*R-squared sebesar 0.0965 itu diobati dengan diferensiasi tingkat pertama $>0.05$ maka dapat disimpulkan bahwa H1 dengan menambahkan d pada variabel y dan $\mathrm{x}$, 
(Tribasuki, Agus (2017) menjadi d(y) c d(x1) $d(x 2) d(x 3) d(x 4)$ sehingga dapat mengatasi masalah autokorelasi dan didapatkan hasil pada Tabel 4.

Hasil estimasi yang diperoleh menunjukan bahwa pada model 2 nilai obs*R-squared $\left(\chi^{2}\right.$ hitung $)=4.749203<\chi^{2}$ tabel $=40.113$ pada level signifikan 5\%. Serta nilai probabilitas obs*R-squared sebesar 0.0931>0.05 maka dapat disimpulkan bahwa H1 ditolak, dan H0 tidak ditolak yang berarti tidak terdapat lagi masalah autokorelasi.

Uji heterokedastisitas bertujuan untuk menguji apakah dalam model penelitian terjadi ketidaksamaan variance dari residual satu pengamatan ke pengamatan yang lain. Dalam penelitian untuk mengetahui adanya heteroskedastisitas dilakukan dengan menggunakan uji white.

Pada model satu persamaan pengaruh variabel bebas terhadap tenaga kerja (TPAK) dengan $\mathrm{n}=31$ dan $\mathrm{k}=2$ maka diperoleh degree offreedom (df) $=29$, dan menggunakan $\alpha=5 \%$ maka diperoleh nilai $\chi^{2}$ tabel sebesar 42.557 . Maka nilai obs*R-squared $<\chi^{2}$ tabel, yaitu $29.02869<42.557$ sehingga dapat disimpulkan model di atas lolos uji heterokedastisitas.

Pada model kedua, persamaan pengvariabel bebas terhadap tingkat pertumbuhan ekonomi di Indonesia, dengan n= 31 dan $\mathrm{k}=4$ maka diperoleh degree of freedom (df) $=27$, dan menggunakan $\alpha=5 \%$ maka diperoleh nilai $\chi^{2}$ tabel sebesar 40.113. Maka nilai obs*R-squared $<\chi^{2}$ tabel, yaitu 20.66415 $<40.113$ sehingga dapat disimpulkan model

Tabel 4. Hasil Uji Autokorelasi dengan diferensiasi Persamaan 2

\begin{tabular}{llll}
\hline Breusch- Godfrey Serial Correlation LM Test & \\
\hline F-statistic & 2.162935 & Prob. F(2,23) & 0.1378 \\
Obs*R-squared & 4.749203 & Prob. Chi-Square(2) & 0.0931 \\
\hline
\end{tabular}

Sumber : data diolah, 2019

Tabel 5.

Hasil Uji White Heteroskedastisitas model 1

\begin{tabular}{|c|c|c|c|}
\hline \multicolumn{4}{|c|}{ Heteroskedasticity Test: White } \\
\hline F-statistic & 13.40025 & Prob. $F(20,10)$ & 0.0001 \\
\hline Obs*R-squared & 29.02869 & Prob. Chi-Square(20) & 0.0717 \\
\hline Scaled explained SS & 23.02869 & Prob. Chi-Square(20) & 0.2874 \\
\hline
\end{tabular}

Sumber : data diolah, 2019 
Tabel 6.

Hasil Uji White Heterokedastisitas model 2

\section{Heteroskedasticity Test: White}

\begin{tabular}{llll}
\hline F-statistic & 2.998906 & Prob. F(12,18) & 0.0175 \\
Obs*R-squared & 20.66415 & Prob. Chi-Square(12) & 0.0555 \\
Scaled explained SS & 11.43355 & Prob. Chi-Square(12) & 0.4922 \\
\hline
\end{tabular}

Sumber : data diolah, 2019

di atas lolos uji heterokedastisitas.

Uji Normalitas bertujuan untuk menguji apakah dalam model regresi variabel pengganggu atau residual memiliki distribusi normal atau tidak. Untuk melihat kenormalan data pada penelitian ini digunakan pengujian menggunakan uji Jarque-Bera.

Residual akan berdistribusi secara normal apabila nilai JB $<\mathrm{X}^{2}$ tabel. Hasil dari uji normalitas yang terdapat pada Gambar
1 dari model persamaan satu, bahwa nilai JB $(1.155333)<X^{2}$ tabel (42.557) dan nilai probability adalah 0.561206 atau 56\%. Maka dapat disimpulkan bahwa residual berdistribusi normal.

Residual akan terdistribusi secara normal apabila nilai JB $<\mathrm{X}^{2}$ tabel. Hasil dari uji normalitas pada Gambar 2, bahwa nilai JB $(0.420064)<X^{2}$ tabel (40.113), dan nilai probability 0.810558 atau $81 \%$. Maka dapat

Gambar 1.

Hasil Uji J-B tes

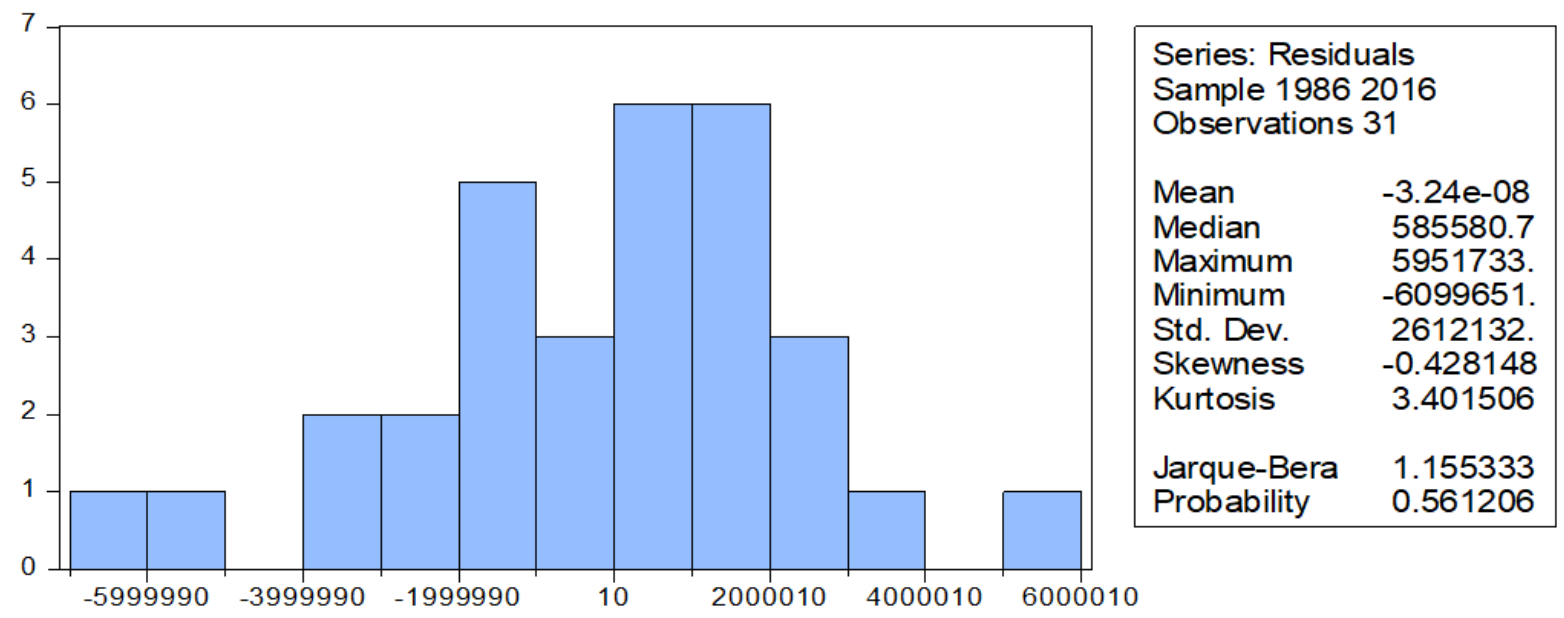

Sumber : data diolah, 2019 
Gambar 2.

\section{Hasil Uji J-B tes}

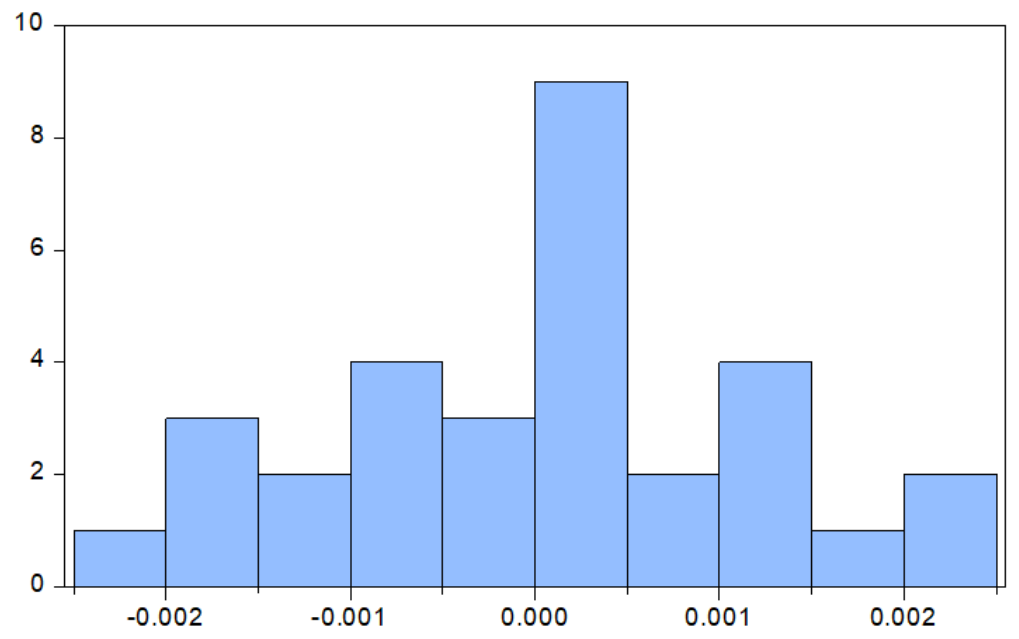

Series: Residuals

Sample 19862016

Observations 31

Mean $\quad-4.01 \mathrm{e}-16$

Median $\quad 8.10 \mathrm{e}-05$

Maximum $\quad 0.002193$

Minimum $\quad-0.002107$

Std. Dev. $\quad 0.001127$

Skewness $\quad-0.067248$

Kurtosis $\quad 2.445815$

Jarque-Bera $\quad 0.420064$

Probability $\quad 0.810558$

Sumber : data diolah, 2019

disimpulkan bahwa residual berdistribusi normal.

Spesifikasi model yang digunakan dalam penelitian ini mengacu pada model pertama dari penelitian yang dilakukan oleh Schultz (2010) tentang pengaruh fertilitas terhadap jumlah pasokan tenaga kerja, penelitian Chrenshaw (1997) tentang pengaruh penduduk usia produktif terhadap jumlah tenaga kerja yang berdampak terhadap output. Model kemudian mengalami modifikasi sesuai dengan variabel dalam penelitian. Selanjutnya, pada model kedua penelitian mengacu pada penelitian Aidi, et al (2016) tentang pengaruh fertilitas, infant mortalitas, tabungan dan belanja pemerintah terhadap pertumbuhan ekonomi. Lebih jelasnya dapat dilihat pada Tabel 7 dan 8 .
Berdasarkan hasil estimasi dapat diketahui bahwa nilai dari variabel bebas pertama adalah angka kelahiran (fertilitas) memiliki nilai koefisien sebesar 2.198558 dengan probabilitas 0.0000 yang berarti fertilitas mempunyai pengaruh yang positif secara signifikan terhadap tingkat partisipasi angkatan kerja. Intepretasinya menunjukkan bahwa untuk setiap penambahan 1 persen angka kelahiran atau fertilitas, dengan asumsi variabel lain ceteris paribus maka akan meningkatkan angka partisipasi angkatan kerja sebesar 2.198558 persen. Hasil ini sesuai dengan penelitian sebelumnya oleh Bloom, D.E, Canning \& Fink (2009) menyebutkan bahwa meningkatnya jumlah angka kelahiran akan meningkatkan rasio usia kerja terhadap total populasi dan meningkatkan pendapatan 


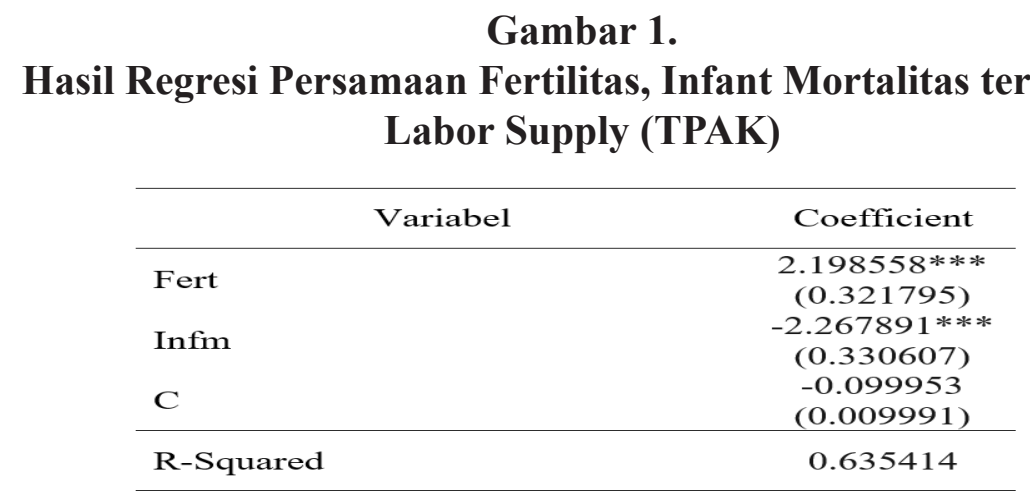

Sumber: Hasil Pengolahan

Ket: variabel signifikan pada tingkat kepercayaan

$10 \%\left(^{*}\right), 5 \%\left({ }^{* *}\right), 1 \%\left({ }^{* *}\right)$

perkapita. Penelitian lain oleh Purnamasari modal dan teknologi (Mankiw, 2009). Maka (2015) yang menyebutkan bahwa pertambahan jumlah angka kelahiran menjadi penyumbang penduduk berpengaruh positif terhadap jumlah dalam komponen sumberdaya manusia sebagai tenaga kerja. Setiap angka kelahiran walaupun tenaga kerja dalam perekonomian. Penelitian tergolong kepada angka usia belum produktif lain yang mendukung adalah Becker (1965) atau angka usia ketergantungan akan tetapi keputusan individu dan alokasi waktu yang menambah jumlah sumberdaya manusia mereka gunakan untuk mengurus rumah tangga. dalam suatu negara yang akan memberikan Aguero (2008) menyebutkan bahwa melahirkan kontribusinya terhadap partisipasi angkatan bukanlah penghalang untuk bekerja sehingga kerja di masa yang akan datang. Sejalan dengan penelitian dari Noviyanto (2016) menyebutkan pengaruh dari faktor demografi yang dalam hal ini adalah fertilitas, dimana angka kelahiran bersifat investasi untuk jangka panjang yang kemudian hari dapat menjadi modal manusia/ tenaga kerja untuk mendorong kegiatan ekonomi. Sesuai dalam teori Solow hal yang kedua yaitu angka kematian bayi terhadap mempengaruhi pertumbuhan ekonomi adalah TPAK. Variabel ini memiliki nilai koefisien sumberdaya manusia(SDM), Sumberdaya alam, sebesar -2.267891 dengan probability 0.0000 
yang berarti bahwa variabel ini berpengaruh secara positif dan signifikan terhadap tingkat partisipasi angkatan kerja di Indonesia. Intepretasinya menunjukkan setiap kenaikan angka kematian bayi sebanyak sebanyak 1 persen maka akan menurunkan jumlah partisipasi angkatan kerja sebesar -2.267891 persen dengan asumsi variabel lain ceteris paribus. Hal ini sesuai dengan penelitian Aidi (2016) yang menyebutkan bahwa angka kematian bayi yang meningkat akan menurunkan pertumbuhan ekonomi melalui berkurangnya angkatan kerja. Karena angka kematian bayi menjadi barometer dalam indikator kesehatan. Untuk mengukur tingkat kesejahteraan penduduk dimana dengan meningkatnya angka kematian bayi mencerminkan angka harapan hidup yang rendah. Penduduk di masa datang akan menjadi penduduk usia produktif, penelitian dari Bloom, D.E, Canning \& Fink (2000) penduduk usia produktif menjadi kapasitas dalam perekonomian untuk melengkapi modal manusia yang diserap dalam kegiatan produktif. Sedangkan menurut penelitian Chrensaw (1997) menyebutkan bahwa peningkatan jumlah penduduk dewasa mendorong pertumbuhan ekonomi melalui bertambahnya angkatan kerja, dengan seiring bertambahnya usia penduduk, mereka akan menjadi pekerja yang kompetitif sehingga memiliki jam kerja yang lebih lama dan pembentukan sumberdaya manusia yang lebih besar.

Pada model yang kedua, diketahui nilai variabel bebas pertama angka kelahiran (fertilitas) memiliki nilai koefisien sebesar -0.050363 dengan probabilitas 0.0000 yang berarti fertilitas mempunyai pengaruh yang negatif secara signifikan terhadap pertumbuhan ekonomi Indonesia.Intepretasinyamenunjukkan bahwa untuk setiap peningkatan 1 persen angka kelahiran atau fertilitas, dengan asumsi variabel lain ceteris paribus maka akan menurunkan angka pertumbuhan ekonomi Indonesia sebesar 0.050363 persen. Hasil ini sesuai dengan penelitian terdahulu yaitu Pancawati (2000) yang menyebutkan bahwa pertumbuhan penduduk yang dalam hal ini merupakan proksi dari fertilitas akan menyebabkan pengaruh negatif terhadap pertumbuhan ekonomi. Pertumbuhan penduduk dengan meningkatnya angka kelahiran yang tinggi tidak diiringi dengan pertumbuhan jumlah output yang tinggi menyebabkan pertambahan penduduk tersebut menjadi beban bagi negara. Menurut 
Olabiyi (2004) Pertumbuhan penduduk yang tinggi menyebabkan banyaknya konsumsi dan mengurangi jumlah sumberdaya alam dan lahan terus berkurang. Hal ini sesuai dengan teori Malthus yang menyatakan bahwa pertumbuhan penduduk lebih cepat dibandingkan jumlah pertumbuhan makanan, awalnya memang pertumbuhan penduduk memberikan dampak positif terhadap pertumbuhan ekonomi, tetapi lama-kelamaan akan menurunkan pertumbuhan ekonomi. Sumberdaya alam yang jumlahnya terbatas sedangkan kebutuhan manusia terus bertambah yang menyebabkan kelangkaan.

Sesuai dengan pandangan Malthusian yang menetapkan hubungan negative antara fertilitas dan pertumbuhan ekonomi (Coale \& Hoover, 1958; Barro, 1997; Klasen, 2002) menyebutkan bahwa pertumbuhan penduduk terhadap pertumbuhan ekonomi. Tingginya

Gambar 1.

Hasil Regresi Persamaan Fertilitas, Infant Mortalitas terhadap Labor Supply (TPAK)

\begin{tabular}{|c|c|}
\hline Variabel & Coefficient \\
\hline LOG(FERT) & $\begin{array}{c}-0.050363 * * * * \\
(0.005173)\end{array}$ \\
\hline Sav & $\begin{array}{c}2.52 \mathrm{E}-14 * * * \\
(0.010500)\end{array}$ \\
\hline LOG(Gov) & $\begin{array}{c}0.005721 \\
(0.000867)\end{array}$ \\
\hline $\mathrm{C}$ & $\begin{array}{c}2.301972 \\
(0.027463)\end{array}$ \\
\hline R-Squared & 0.994626 \\
\hline
\end{tabular}

yang cepat akibat dari tingkat kesuburan yang tinggi akan menyebabkan kemiskinan terutama akibat ekspansi populasi yang menyiratkan modal terhadap tenaga kerja yang menurun. Penelitian lain menurut Onkuwa (2006) bertambahnya jumlah penduduk berdampak negatif terhadap pembangunan karena sebagian besar anggaran negara yang dapat digunakan untuk tujuan pembangunan seperti infrastruktur akan lebih banyak dikonsumsi untuk kebutuhan penduduk seperti biaya kesehatan, pendidikan, sarana umum, dan lain-lain.

Penelitian Aidi et al., (2016) menyebutkan bahwa ukuran populasi yang sangat besar tidak hanya membuat perencanaan pembangunan menjadi sulit bagi suatu negara tetapi juga menimbulkan ancaman yang signifikan
Sumber: Hasil Pengolahan

Ket: variabel signifikan pada tingkat kepercayaan $10 \%\left({ }^{*}\right), 5 \%\left({ }^{* *}\right), 1 \%\left(^{* * *}\right)$ 
angka kelahiran memang menjadi masalah bagi signifikan terhadap pertumbuhan ekonomi banyak negara-negara berkembang di dunia. Indonesia. Intepretasinya menunjukkan Semakin banyak jumlah penduduk jika tidak bahwa untuk setiap peningkatan kematian diiringi dengan peningkatan kualitasnya akan bayi sebanyak 1 persen atau infant mortalitas, terus memberikan pengaruh memburuknya dengan asumsi variabel lain ceteris paribus kondisi perekonomian negara. Menurut maka akan menurunkan angka pertumbuhan Todaro dan Smith (2012) pengendalian jumlah ekonomi Indonesia sebesar 0.048367 persen. penduduk dapat dilakukan dengan dua checks Hal ini sesuai dengan penelitian Olabiyi yaitu yang pertama negative/ preventive checks (2004) angka kematian bayi yang menurun yaitu pengendalian jumlah angka kelahiran menggambarkan membaiknya kesejahteraan dengan cara menunda usia perkawinan dan penduduk dan perekonomian secara umum, pengendalian moral. Hal ini dikhususkan disisi lain, meningkatnya angka kematian bagi penduduk golongan rendah/miskin. bayi mengurangi jumlah penduduk, dengan Sedangkan yang kedua adalah positive checks jumlah penduduk yang terkendali jumlahnya yaitu berkurangnya jumlah penduduk akibat akan mendorong pertumbuhan ekonomi. kematian, penyakit dan kelaparan. Perubahan Berdasarkan hasil penelitian menyebutkan struktur produksi dengan menghilangkan arti bahwa peningkatan angka kematian bayi penting keluarga sebagai unit produksi dan membuat pertumbuhan ekonomi ikut menurun meningkatkan peran wanita dalam bekerja dan sebaliknya berkurangnya angka kematian juga dapat mengendalikan penurunan angka bayiakan meningkatkan pertumbuhan ekonomi. kelahiran (Coale \& Hoover, 1958; Hover, 1995). Hal ini menjadi gambaran bahwa kondisi Berdasarkan hasil model persamaan ke kesehatan yang baik antar ibu dan anak serta dua, variabel independen kedua adalah infant layanan kesehatan sebagai upaya menurunkan mortalitas atau angka kematian bayi memiliki angka kematian bayi untuk meningkatkan nilai koefisien sebesar -0.048367 dengan kesejahteraan penduduk.

probabilitas 0.0001 yang berarti angka kematian Sejalan dengan penelitian Noviyanto bayi mempunyai pengaruh yang negatif secara (2016) terjadi hubungan negatif antara kematian 
bayi dan pertumbuhan ekonomi. Angka kematian bayi tidak hanya mempengaruhi pertumbuhan penduduk tetapi juga sebagai indikator dalam pengukuran tingkat kesuksesan dalam kesehatan masyarakat, sehingga digunakan dalam ukuran kemajuan Indeks Pembangunan Manusia. Penelitian dari Kibirige (1997) secara teoritis diharapkan ketika jumlah output meningkat atau pertumbuhan ekonomi meningkat maka akan tersedia cukup pengeluaran untuk meningkatkan kesehatan bayi dan mengurangi angka kematian bayi. Meningkatnya angka kematian bayi mencerminkan angka harapan hidup yang rendah sehingga memberikan dampak negatif terhadap pertumbuhan ekonomi. Kondisi di Indonesia sesuai dengan teori transisi demografi menyebutkan pada umumnya angka kematian bayi berkurang diikuti dengan penurunan tingkat kesuburan atau berkurangnya angka kelahiran.

Variabel independen ketiga adalah tabungan atau saving memiliki nilai koefisien sebesar 2.52E-14 dengan probabilitas 0.0029 yang berarti angka tabungan mempunyai pengaruh yang positif secara signifikan terhadap pertumbuhan ekonomi Indonesia. Setiap kenaikkan 1 persen tabungan maka akan meningkatkan $2.52 \mathrm{E}-14$ persen pertumbuhan ekonomi di Indonesia. Pengaruh tabungan terhadap pertumbuhan ekonomi adalah positif, Dimana dalam hal ini tabungan adalah sumber dana yang digunakan oleh negara dalam kegiatan pembangunan yang juga ditambah dengan pinjaman luar negeri. Sesuai dengan penelitian dari Olabiyi (2004) yang juga menggunakan tabungan sebagai variabel kontrol dalam pertumbuhan ekonomi, menyebutkan bahwa kegiatan tabungan oleh masyarakat dapat menjadi penanaman modal yang dapat digunakan oleh investor yang akan melakukan kegiatan produktivitas dalam perekonomian. Menurut teori Harrod-Domar tabungan menjadi sangat penting bagi pertumbuhan ekonomi yang mekanismenya lewat pertumbuhan investasi. $\mathrm{I}=\mathrm{f}(\mathrm{S})$ dengan semakin besar jumlah tabungan maka kemampuan negara melakukan investasi juga semakin besar.

Menurut penelitian Febriani (2007) menyebutkan bahwa implikasi dari meningkatnya jumlah tabungan-tabungan akan meningkatkan laju pertumbuhan ekonomi. Hal ini karena tabungan akan menambah dalam kegiatan investasi, bagian dari pendapatan yang tidak dikonsumsikan disebut dengan tabungan masyarakat, dan penggabungan tabungan 
masyarakat dan pemerintah membentuk belanja pemerintah maka akan meningkatkan tabungan nasional yang dapat digunakan sebagai 0.005721 persen pertumbuhan ekonomi di sumber dana investasi. Lain halnya penelitian Indonesia. Sesuai dengan penelitian Aidi,et al dari Aidi, et al (2016) dan Nwazake (2011) di (2016) menyebutkan bahwa belanja pemerintah negara berkembang lain yang menunjukkan hasil mendorong pertumbuhan ekonomi seperti berlawanan yaitu hasil negatif dari tabungan penggunaan dalam pembangunan ekonomi dan terhadap pertumbuhan ekonomi, dimana meningkatkan pelayanan masyarakat untuk jumlah tabungan membuat dana yang ditabung bidang sarana dan prasarana seperti infrastruktur, berjumlah sedikit dan tidak dapat digunakan kesehatan dan pendidikan guna meningatkan untuk kegiatan investasi tetapi lebih kepada kesejahterakan masyarakat. Sifat dari belanja kepada konsumsi karena jumlah masyarakatnya pemerintah ini jangka panjang sebagai modal yang banyak. Pendapatan masyarakat yang untukmeningkatkan pembangunan dalam sektor rendah menyebabkan tabungan masyarakat kesehatan, pendidikan dan daya beli masyarakat. menjadi rendah. Untuk kegiatan pembangunan dibutuhkan tabungan dan investasi dalam jumlah besar (Sukirno,2006). Tabungan menjadi syarat

\section{SIMPULAN}

Berdasarkan hasil penelitian di atas, penting untuk meningkatkan pertumbuhan maka kesimpulan yang dapat diambil adalah ekonomi. penggunaan tabungan untuk pihak pertama, variabel dinamika penduduk yang swasta perlu di dorong untuk melakukan digunakan yaitu fertilitas dan infant mortalitas kegiatan produktivitas dalam ekonomi. memberikan pengaruh negatif terhadap

Variabel independen keempat adalah belanja pemerintah atau government expenditure pertumbuhan ekonomi di Indonesia. Kondisi di memiliki nilai koefisien sebesar 0.005721 Indonesia mengikuti mazhab kaum pesimis dari dengan probabilitas 0.0000 yang berarti Malthusian, yang menyebutkan bahwa semakin meningkatnya jumlah populasi akan secara terus belanja pemerintah mempunyai pengaruh yang menerus membebani kemampuan masyarakat positif secara signifikan terhadap pertumbuhan untuk memenuhi kebutuhannya sendiri. ekonomi Indonesia. Setiap kenaikkan 1 persen Semakin bertambahnya jumlah penduduk maka 
akan membuat pertumbuhan ekonomi menurun karena jumlah penduduk yang bertambah menimbulkan masalah seperti perencanaan yang sulit dan pembelanjaan pemerintah yang meningkat untuk kependudukan.

Selanjutnya, variabel angka kematian bayi memberikan pengaruh negatif terhadap pertumbuhan ekonomi. Semakin besar jumlah angka kematian bayimaka pertumbuhan ekonomi menurun. Hal ini menggambarkan masalah dalam kesehatan secara keseluruhan baik itu kesehatan ibu hamil, perbaikan gizi, kesehatan bayi dan pelayanan kesehatan. Angka kematian bayi berkaitan dengan peningkatan angka harapan hidup di Indonesia. Sebelum melihat pengaruh variabel dinamika penduduk terhadap pertumbuhan ekonomi, diuji terlebih dahulu terhadap jumlah angkatan kerjaHasil penelitian fertilitas memberikan pengaruh positif terhadap jumlah partisipasi angkatan kerja di Indonesia. Dan infant mortalitas memberikan pengaruh negatif terhadap angkatan kerja. Variabel kontrol dalam penelitian adalah tabungan dan belanja pemerintah juga memberikan pengaruh positif terhadap pertumbuhan ekonomi.

Kedua, faktor yang paling mempengaruhi dalam variabel dinamika penduduk terhadap pertumbuhan ekonomi adalah fertilitas. Pertumbuhan penduduk yang merupakan proksi dari fertilitas menghasilkan penduduk yang terus meningkat setiap tahunnya. Pengaruh negatif yang dihasilkan oleh fertilitas terhadap pertumbuhan ekonomi Indonesia apabila tidak dikendalikan dengan benar akan menimbulkan permasalahan bagi perekonomian jangka panjang. Mulai dari pertumbuhan penduduk yang lebih tinggi dibandingkan pertumbuhan output, bertambahnya penduduk tidak sebanding dengan jumlah lapangan pekerjaan yang tersedia sehingga nantinya akan menimbulkan masalah sosial dan ekonomi seperti kelaparan, kriminalitas dan pengangguran. Serta bertambahnya jumlah penduduk akan membuat jumlah lahan terus berkurang sedangkan kebutuhan terus meningkat.

Pertumbuhan penduduk yang sangat cepat akan banyak memberikan dampak negatif terhadap perekonomian. Tidak hanya masalah angka kelahiran yang tinggi, tetapi bagaimana manusia yang dilahirkan menjadi manusia yang berkualitas dan mampu berdaya saing sehingga memberikan kontribusi untuk menjadi tenaga kerja yang produktif untuk kemajuan ekonomi. Untuk menghindari perangkap Malthus yaitu 
dengan upaya mengurangi kesuburan dan memilih untuk memiliki jumlah keluarga yang kecil untuk peningkatan investasi setiap anak yang lahir di masa yang akan datang.

\section{REFERENSI}

Aidi, H et al., (2016). Population Dynamics and Economic Growth in Nigeria. Journal of Economics and Sustanable Development ISSN 2222-1700 Vol.7 No.15. Department of Economics, University of Nigeria. Nigeria.

Badan Pusat Statistik. (2018). Data Produk Domestik Bruto Menurut Penggunaan Atas Dasar Harga Konstan 2010. (Diakses pada 22 Februari 2019).

Badan Perencanaan Pembangunan Nasional (2013). Proyeksi Penduduk Indonesia 2010-2035. BPS. Jakarta

Badan Perencanaan Pembangunan Nasional (2009). Penyebab dan Dampak Krisis. BPS. Jakarta. Website:https://www. bappenas.go.id/files/2413/5027/3724. (Diakses pada 15 Juni 2019).

Barro, R. (1997). Economic Growth in a Cross Section of Countries. The Quaterly Journal Economics. Vol 106. No 2. Pp 407-443.

Becker, G, S. (1965). An economic analysis of fertility. In Demographic and Economic Change in Developed Countries. Princeton, NJ: Princeton University Press and NBER.

BKKBN. (2018). Profil Kependudukan dan Pembangunan di Indonesia Tahun 2018. Jakarta.

Bloom, D.E, et al (2000). Population Dynamics and Economic Growth in Asia. Population and Development Review, Vol. 26, Supplement: Population and Economic. JSTOR. Population Council.

Bloom, D.E, Canning \& Fink (2009). Fertility, female labor force participation, and the demographic dividend. J.Econ Growth. DOI $\quad 10.1007 / \mathrm{s} \quad 10887-009-9039-9$. Program on the Global Demography of
Aging. Harvard University. Boston.

Boserup, Ester. (1981). Population and Technological Change. USA: The University of Chicago. Chicago.

BPS. (2015). Data Sensus Penduduk (diakses pada 2 Februari 2019).

Buku Demografi Dan Kependudukan. (2017). FEB Universitas Padjadjaran. Bandung.

Coale, A. J., \& Hoover, E. (1958). Population Growth and Economic Development in Low Income Countries. Princeton, New Jersey: Princeton University Press. Princeton.

Dumairy. (1996). Perekonomian Indonesia. Erlangga: Jakarta.

Febriani (2007) Pengaruh Tabungan Terhadap Pertumbuhan Ekonomi. Tamsis. http:// journal.untas.pdg.ac.id. (Diakses pada 3 Juli 2019).

Ghozali, Imam. (2013). Aplikasi Analisis Multivariate dan Ekonometrika Teori Konsep dan Aplikasi Eviews. Badan Penerbit Universitas Diponegoro. Semarang.

Jhingan. (2000). Ekonomi Pembangunan dan Perencanaan, terjemahan D.Guritno. PT. Raja Grafindo Persada. Jakarta

Lucas, D., Mc Donald, P \& Young, C. (1990). Pengantar Kependudukan. Terjemahan. Yogyakarta : Gadjah Mada University Press.

Mankiw, Gregory, N. (2009). Makroekonomi Edisi keenam. Worth Publishers News York and Basingstock. Terjemahan. Penerbit Erlangga: Jakarta.

Noviyanto (2016) Pengaruh Faktor Demografi Dan Tenaga Kerja terhadap Pertumbuhan Ekonomi Jawa Timur. http://repository. unair.ac.id/52974 (Diakses pada 3 Juli 2019).

Olabiyi A.,K. (2004). The Effects of Population Dynamic Growth in Nigeria. Research Journal. Vol.2 No.1 January. ISSN 23478233.

Pancawati, Neni. (2000). Pengaruh Rasio Kapital Tenaga Kerja, Tingkat Pendidikan, Stok Kapital, dan Pertumbuhan Penduduk terhadap Tingkat Pertumbuhan GDP Indonesia. Jurnal Ekonomi dan Bisnis

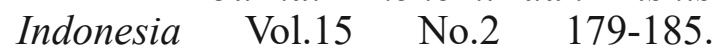


Universitas Gadjah Mada. Yogyakarta.

Purnamasari, Dian (2015). Penduduk dan Pertumbuhan Ekonomi sebuah penjelasan empiris baru. Skripsi Universitas Diponegoro. Semarang.

Schultz, T.P. (1990). Testing the Noclassical Model of Family Labor supply and Fertility. The Journal of Human Resources. 25(4).559.doi 10.2307/145669. JSTOR.

Simon, JL. (1986). Theory of Population and Economic growth. Oxford, United Kingdom. Basil Blackwell. Xi.232 p. USAID. Doc. Number 048526. United Kingdom.

Sukirno, S. (2006). Mikro Ekonomi Teori Pengantar. Jakarta. PT Raja Grafindo Persada.

Stephen, D, et al., (2003) . The Economic Impact of Migration: A survey. Hamburgisches Welt-WirtschaftsArchiv (HWWA) .Hamburg Institute of International Economics. ISSN 16164814.

The World Bank. (2015). Data World Bank: http://data.worldbank.org/indicator (diakses pada 10 Januari 2019 pukul 21.26 WIB)

Todaro \& Michael P. (2011). Pembangunan Ekonomi Jilid 1 Edisi 10. Jakarta: Erlangga.

World Development Indicator. (2017). https: //data.worldbank. org / country/indonesia. (diakses pada tanggal 10 September 2018 pukul 13.00 WIB). 